\title{
Development of the Holocene foredune plain in the Narva-Joesuu area, eastern Gulf of Finland
}

\author{
Alar ROSENTAU ${ }^{1,2, *}$, Argo JOELEHT' ${ }^{1}$, Jüri PLADO ${ }^{1}$, Raivo AUNAP $^{3}$, Merle MURU ${ }^{3}$ and Kari O. ESKOLA ${ }^{4}$ \\ 1 Department of Geology, University of Tartu, Ravila 14A, 50411 Tartu, Estonia \\ 2 Institute of History and Archaeology, University of Tartu, Lossi 3, 51003 Tartu, Estonia \\ 3 Department of Geography, University of Tartu, Vanemuise 46, 51014 Tartu, Estonia \\ 4 Finnish Museum of Natural History, University of Helsinki, Gustaf Hällströmin katu 2, 00014 Helsinki, Finland
}

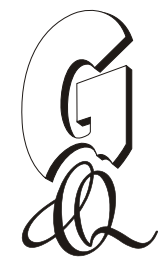

\begin{abstract}
Rosentau A., Joeleht A., Plado J., Aunap R., Muru M. and Eskola K.O. (2013) Development of the Holocene foredune plain in the Narva-Joesuu area, eastern Gulf of Finland. Geological Quarterly, 57 (1): 89-100, doi: 10.7306/gq.1077

The morphogenesis and inner structure of the Holocene foredune plain in the Narva-Joesuu area, eastern Gulf of Finland, were studied using optically stimulated luminescence (OSL) dating, ground-penetrating radar (GPR) study and interpretation of airborne LIDAR elevation data. The results show that the Narva-Joesuu foredune plain consists of ca. 100 parallel coastal foredune ridges built of well-sorted fine sand underlain by gently $\left(\sim 7^{\circ}\right)$ seaward-dipping sandy beach deposits. The distal part of the plain, which consists of at least 15 ridges, formed during the regressive phase of the Ancylus Lake/Early Litorina Sea, serving as a barrier for the lagoon behind it. A larger portion of ridges, with an average progradation rate of $0.26 \mathrm{~m} \mathrm{a}^{-1}$, formed under conditions of falling relative sea level during the Litorina regression and was separated from the older foredune succession by a hiatus related to the Litorina transgression at $8.5-7.3 \mathrm{cal}$. ka BP. In the highest central part of the plain the foredune growth was interrupted by foredune instability and a re-blowing episode dated to $5.4 \pm 0.9 \mathrm{ka}$ BP which may correlate with a larger regional cooling at 5.8-5.1 cal. ka BP in the North Atlantic and central Europe. During the last 3000 years, the foredune progradation rate decreased to $0.19 \mathrm{~m} \mathrm{a}^{-1}$, most probably because of decelerated land-uplift and increased human impact due to coastal protection.
\end{abstract}

Key words: Holocene, Baltic Sea, foredunes, luminescence dating, ground-penetrating radar, LIDAR.

\section{INTRODUCTION}

Foredunes have been defined as shore-parallel dune ridges, formed on the top of the backshore by aeolian sand deposition within vegetation while systematic beach progradation over time frames of tens to thousands of years may lead to the development of wide foredune plains (Hesp, 2002). Their formation and morphology can provide information about Holocene sea level changes and climatic events, but also about changes in sediment supply, vegetation cover and wave energy (Hesp, 2002). In the southern Baltic Sea basin, episodes of foredune instability and formation of blowouts have been related to colder and stormier conditions, the so-called LIA (Little Ice Age)-type events and systematic accretion and foredune plain growth with milder and calmer climate, and an intact vegetation cover (Reimann et al., 2011).

The $2.5 \mathrm{~km}$ wide foredune plain in the Narva-Joesuu area consists of fine sandy deposits forming approximately 80 parallel ridges in a zone running for $14 \mathrm{~km}$ adjacent to the present-day shoreline (Lepland et al., 1996; Fig. 1). Martin and

\footnotetext{
* Corresponding author: alar.rosentau@ut.ee
}

Received: May 25, 2012; accepted: October 16, 2012; first published online: February 28, 2013
Schwartz (1991) proposed that this ridge system consists of uniformly straight and parallel ridges built by wave action and of sinuous, irregular ridges formed by a combination of wave and aeolian processes. On the basis of three dates obtained from thermoluminescence analyses, they suggested the formation of the beach ridge system during the Litorina Sea stage. Considering these dates and biostratigraphical analyses of the lagoonal deposits in Leekovosoo mire (Fig. 1C), Lepland et al. (1996) argued that the SE part of the Narva-Joesuu foredune plain had formed already before the Litorina Sea stage, most probably during the regression of the Ancylus Lake, and the highest central part of the ridge system formed most likely during the culmination of the Litorina Sea transgression. Based on the geomorphology and the mineralogical analyses they concluded that uniformly straight ridges have been built by aeolian processes and correspond to the parallel dune (foredune) type in Bird's (1984) classification, while on the highest central part of the plain, where the forms are irregular and higher, the initial foredunes were subjected to later aeolian processes.

In the current paper the foredune complex in the Narva-Joesuu area is investigated by ground-penetrating radar, interpretation of airborne LIDAR elevation data and by optically stimulated luminescence (OSL) dating in order to clarify the development of the ridge system and its relations to sea level and climatic events. 


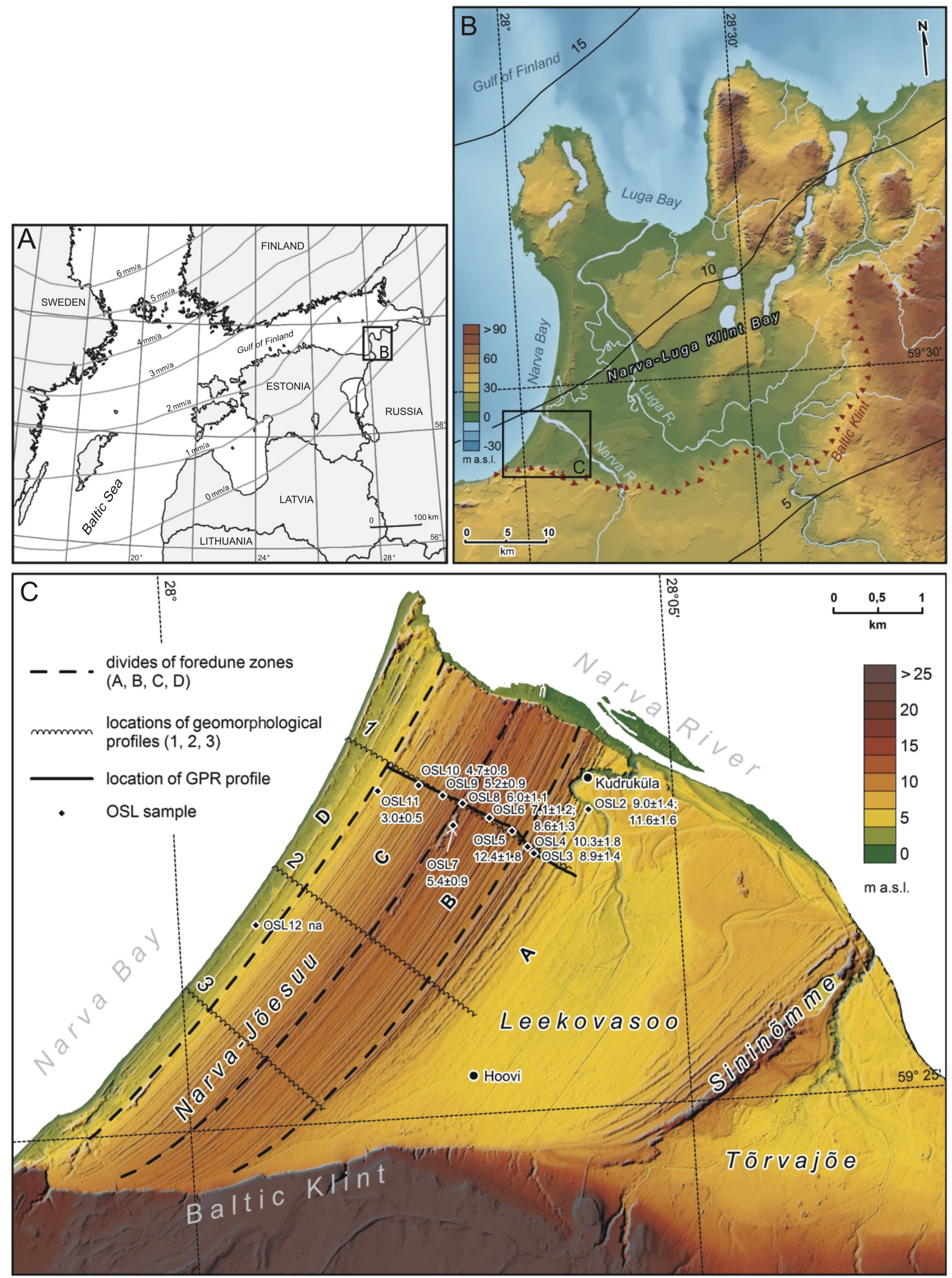

Fig. 1A - overview map with present-day apparent land uplift isobases after Ekman (1996); B - Narva-Luga Klint Bay area with location of isobases of the Litorina Sea level high-stand (m a.s.l.; after Saarse et al., 2003); C - digital elevation model for the Narva-Joesuu foredune plain and surrounding areas with OSL sampling sites and ages and location of geomorphological and geophysical profiles discussed in the text 


\section{GEOLOGICAL SETTING}

The Narva-Joesuu foredune plain is located in the western part of Narva-Luga Klint Bay, an extensive indentation in the klint line, part of the Narva-Luga coastal lowland situated in NE Estonia and NW Russia (Fig. 1). The area is characterized by slow but uneven glacioisostatic land uplift and complex water level changes with alternating lake (Baltic Ice Lake and Ancylus Lake) and marine (Yoldia Sea and Litorina Sea) stages (Figs. 1 and 2). Lepland et al. (1996) carried out a detailed study into the geomorphology, bio- and lithostratigraphy, with magnetic analysis in combination with radiocarbon chronology in the Estonian part of Narva-Luga Klint Bay. They recognized the highest shoreline of the Ancylus Lake at an altitude of $9 \mathrm{~m}$ around 9.2-9.1 uncal. ka BP in the Sininomme beach ridge and estimated that the highest water level of the Litorina Sea was at an altitude of $10 \mathrm{~m}$ in the Narva-Joesuu ridge system (Fig. 1B). However, they did not provide any dates from the Narva-Joesuu area. Martin and Schwartz (1991) dated the Narva-Joesuu beach ridge system using thermoluminescence (TL) analyses and obtained a number of conflicting ages. Despite this, they published three dates with successively younger ages: $6.1,5.4$ and $5.0 \mathrm{ka}$ BP for the central part of the ridge system. Based on study of lake deposits in the eastern part of Narva-Luga Klint Bay Sandgren et al. (2004) identified the highest water level of the Litorina Sea at an altitude of $10 \mathrm{~m}$ at 7.6-7.2 cal. ka BP and suggested an additional minor $(1 \mathrm{~m})$ transgression wave around 6.5 cal. ka BP (Fig. 2). Rosentau et al. (2013) compiled a Holocene shore displacement curve for the Narva-Luga area by using data from isolated lake basins from Sandgren et al. (2004), and studying coastal landform elevations, buried peat layers and Stone Age settlement sites in NE Estonia and NW Russia (Fig. 2).

\section{MATERIAL AND METHODS}

\section{LUMINESCENCE DATING}

All samples for dating were collected from the original deposit to avoid post-depositional mixing of the sediments by roots or soil formation processes. Samples OSL2 and 7 were taken from the re-blown parts of the foredune ridges, samples OSL3-6 and OSL8-12 from the shore parallel (foredune) ridges (Fig. 1C). The sampling depth was 0.8-1.7 m (Table 1) and sampled material was fine-grained sand (Table 2). The altitudes and locations of OSL samples were measured on site. Basic elevation network was determined by RTK GPS equipment. Additional levelling from basic RTK GPS network points to sample sites under dense canopy was carried out by high precision total station (tachometer). Only short sights were used in order to minimize error propagation. Overall elevation accuracy was estimated to be better than $10 \mathrm{~cm}$.

Measurements were made on quartz. The original samples were sieved and the grain size interval of 210-297 $\mu \mathrm{m}$ was selected for further preparation. After selection the quartz grains were density-separated from the material. The separated quartz was then treated with $\mathrm{HF} 40 \% / 1 \mathrm{~h}$ and $\mathrm{HCl} 10 \% / 30$ min to etch away the surface layer.

The samples were measured by the optically stimulated luminescence (OSL) dating method with the an upgraded Risø TL-DA-12 reader (Bøtter-Jensen and Duller, 1992; BøtterJensen et al., 1999). The measuring routine was based on single aliquot regeneration (SAR) protocol (Murray and Wintle, 2000). Beta radiation dose-rate measurements were performed for the samples with a Risø GM-25-5 beta counter. In the absence of gamma radiation dose-rate measurements, the total dose rate was estimated from the beta count-rate measure-

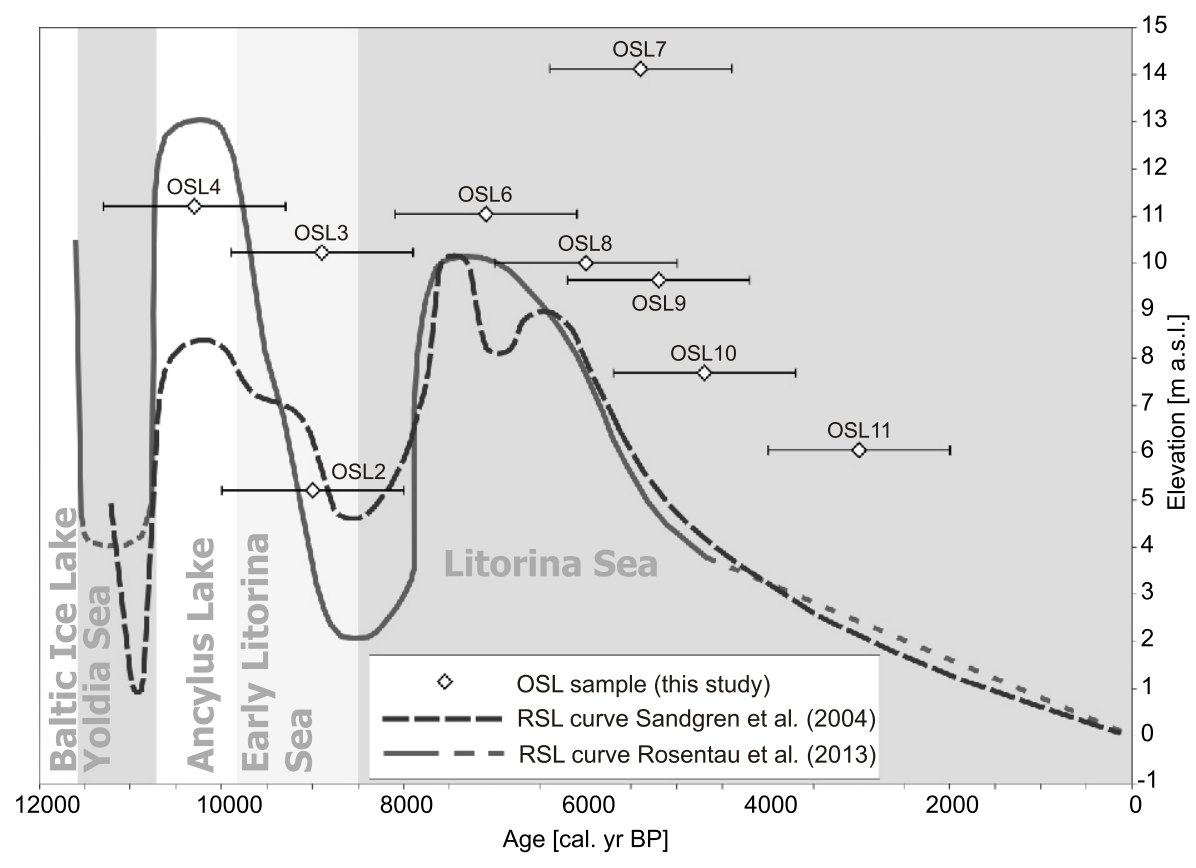

Fig. 2. Holocene water level change curves for the Narva-Luga Klint Bay area according to Sandgren et al., (2004) and Rosentau et al. (2013) compared to OSL ages from Narva-Joesuu

The OSL sample altitudes are corrected against differential isostatic uplift; Baltic Sea stages are according to Andrén et al. (2011) 
Results of OSL dating

\begin{tabular}{|c|c|c|c|c|c|c|c|c|c|}
\hline Lab. No. & $\begin{array}{c}\text { Sample } \\
\text { no. }\end{array}$ & Latitude & Longitude & $\begin{array}{c}\text { Sample } \\
\text { depth }[\mathrm{m}]\end{array}$ & $\begin{array}{c}\text { Surface } \\
\text { altitude } \\
{[\mathrm{m}]}\end{array}$ & $\begin{array}{l}\text { Number of } \\
\text { aliquots }\end{array}$ & $\begin{array}{l}\text { Total dose } \\
\text { rate [mGy/a] }\end{array}$ & $\begin{array}{l}\text { Equal dose } \\
{[\text { [Gy] }}\end{array}$ & $\begin{array}{c}\mathrm{Age} \\
{[\mathrm{ka} \mathrm{BP}]}\end{array}$ \\
\hline \multirow{2}{*}{ Hel-TL04218 } & \multirow{2}{*}{ OSL2 } & \multirow{2}{*}{$59^{\circ} 26^{\prime} 49^{\prime \prime}$} & \multirow{2}{*}{$28^{\circ} 04^{\prime} 23^{\prime \prime}$} & \multirow{2}{*}{1.5} & \multirow{2}{*}{6.7} & 3 & $1.84 \pm 0.23$ & $16.5 \pm 1.4$ & $9.0 \pm 1.4$ \\
\hline & & & & & & 4 & $1.84 \pm 0.23$ & $22.3 \pm 1.3$ & $12.1 \pm 1.7$ \\
\hline Hel-TL04219 & OSL3 & $59^{\circ} 26^{\prime} 34^{\prime \prime}$ & $28^{\circ} 03^{\prime} 42^{\prime \prime}$ & 1.4 & 11.0 & 8 & $1.53 \pm 0.20$ & $13.7 \pm 1.2$ & $8.9 \pm 1.4$ \\
\hline Hel-TL04220 & OSL4 & $59^{\circ} 26^{\prime} 37^{\prime \prime}$ & $28^{\circ} 03^{\prime} 38^{\prime \prime}$ & 1.3 & 12.3 & 10 & $1.83 \pm 0.26$ & $18.7 \pm 1.9$ & $10.3 \pm 1.8$ \\
\hline Hel-TL04221 & OSL5 & $59^{\circ} 26^{\prime} 43^{\prime \prime}$ & $28^{\circ} 03^{\prime} 27^{\prime \prime}$ & 1.4 & 11.1 & 4 & $1.82 \pm 0.22$ & $22.5 \pm 1.7$ & $12.4 \pm 1.8$ \\
\hline \multirow{2}{*}{ Hel-TL04222 } & \multirow{2}{*}{ OSL6 } & \multirow{2}{*}{$59^{\circ} 26^{\prime} 48^{\prime \prime}$} & \multirow{2}{*}{$28^{\circ} 03^{\prime} 11^{\prime \prime}$} & \multirow{2}{*}{1.4} & \multirow{2}{*}{11.9} & 9 & $1.62 \pm 0.22$ & $11.5 \pm 1.0$ & $7.1 \pm 1.2$ \\
\hline & & & & & & 7 & $1.62 \pm 0.22$ & $14.6 \pm 0.9$ & $9.0 \pm 1.4$ \\
\hline Hel-TL04223 & OSL7 & $59^{\circ} 26^{\prime} 46^{\prime \prime}$ & $28^{\circ} 02^{\prime} 45^{\prime \prime}$ & 1.2 & 14.8 & 9 & $1.53 \pm 0.21$ & $8.3 \pm 0.8$ & $5.4 \pm 0.9$ \\
\hline Hel-TL04224 & OSL8 & $59^{\circ} 26^{\prime} 54^{\prime \prime}$ & $28^{\circ} 02^{\prime} 53^{\prime \prime}$ & 1.4 & 10.9 & 10 & $1.43 \pm 0.19$ & $8.5 \pm 1.0$ & $6.0 \pm 1.1$ \\
\hline Hel-TL04225 & OSL9 & $59^{\circ} 26^{\prime} 57^{\prime \prime}$ & $28^{\circ} 02^{\prime} 39^{\prime \prime}$ & 1.6 & 10.8 & 9 & $1.38 \pm 0.20$ & $7.2 \pm 0.8$ & $5.2 \pm 0.9$ \\
\hline Hel-TL04226 & OSL10 & $59^{\circ} 27^{\prime} 02^{\prime \prime}$ & $28^{\circ} 02^{\prime} 22^{\prime \prime}$ & 0.8 & 8.2 & 14 & $1.31 \pm 0.18$ & $6.1 \pm 0.6$ & $4.7 \pm 0.8$ \\
\hline Hel-TL04227 & OSL11 & $59^{\circ} 27^{\prime} 00^{\prime \prime}$ & $28^{\circ} 01^{\prime} 53^{\prime \prime}$ & 1.3 & 7.0 & 15 & $1.47 \pm 0.19$ & $4.4 \pm 0.4$ & $3.0 \pm 0.5$ \\
\hline Hel-TL04228 & OSL12 & $59^{\circ} 26^{\prime} 14^{\prime \prime}$ & $28^{\circ} 00^{\prime} 19^{\prime \prime}$ & 1.7 & 5.1 & 14 & na & na & na \\
\hline
\end{tabular}

na - not analysed

ments by using experimentally determined relations based on a set of dose-rate data previously collected by neutron activation measurements and gamma/beta spectroscopy (Ankjægaard and Murray, 2007).

Error analysis of the results follows the law of error propagation and guidelines described by Aitken (1985). Errors were determined separately for each sample and correspond to the $1 \sigma$ confidence level. The analysis assumes water contents of $W_{\text {sample }}=W_{\text {soil }}=0.2$ and fractional water uptake $F=0.8 \pm 0.2$. The estimated uncertainty of $F$ induces $3.5 \%$ systematic uncertainty in all results and has been taken into account by quadratical summing. Change in water content from $W=0.2$ to 0.1 or 0.3 induces a 8 or $+8 \%$ effect into the final ages, respectively. However, the latter uncertainty was not included in the final results and is given just for information. Uncertainties were induced by the beta counting statistics and by the procedure for estimating the total dose rate based on the existing count-rate/dose-rate data. Since the gamma-radiation dose rates are based on estimation, the resulting uncertainty is slightly larger than those from measurements. The uncertainties in the total dose-rate determination are $12-14 \%$, corresponding reasonably to the estimates made with a large dataset by Ankjærgaard and Murray (2007). Together with the uncertainties due to luminescence measurements the total errors ranged within $14-18 \%$.
Before the age distributions were made some rejection criteria were used for single aliquots. The recycling ratio limit (the difference in the OSL intensity between the first and the last regeneration having the same doses) was put at $10 \%$. The maximum error in the constant test dose, measured between regeneration doses, was put at $10 \%$. Maximum palaeodose fitting error for a single aliquot was put at $25 \%$. The aliquots that did not meet these criteria were left out of the analyses. Only the results within the 95\% confidence level $(2 \sigma)$ were included in the age distribution analyses based on the radial plot analysis described by Galbraith (1990). Histograms were compiled on the basis of the selected data and the palaeodose was evaluated.

\section{AIRBORNE LIDAR ELEVATION DATA}

Airborne LIDAR elevation data collected in the years 2008-2011 by the Estonian Land Board are used here for geomorphological analyses. Scanning was done with a Leica ALS50-/l scanner by implementing a sinusoidal multipulse (MPiA) scan pattern, where the possible number of reflections per impulse is 1-4. Flying took place at an altitude of $2400 \mathrm{~m}$, whereby the illuminated footprint diameter was $0.54 \mathrm{~m}$ and point density approximately 0.45 points per $\mathrm{m}^{2}$ with computational vertical accuracy of $0.07-0.12 \mathrm{~m}$. The data points repre-

Table 2

Granulometric composition of selected OSL samples

\begin{tabular}{|l|c|c|c|c|c|c|c|}
\hline \multirow{2}{*}{ Fraction [ m] } & \multicolumn{3}{|c|}{ Foredune ridges } & \multicolumn{3}{c|}{ Re-blown ridges } & \multirow{2}{*}{ Present } \\
& OSL3 & OSL4 & OSL5 & OSL6 & OSL2 & OSL7 & backshore \\
\hline$>2000$ & 0.0 & 0.0 & 0.0 & 0.0 & 0.0 & 0.0 & 0.0 \\
\hline $2000-1000$ & 0.0 & 0.0 & 0.0 & 0.0 & 0.0 & 0.0 & 0.0 \\
\hline $1000-500$ & 0.1 & 0.0 & 0.1 & 0.0 & 0.0 & 0.0 & 0.0 \\
\hline $500-250$ & 10.1 & 6.1 & 16.4 & 13.7 & 2.8 & 12.3 & 3.0 \\
\hline $250-125$ & 89.1 & 93.2 & 82.1 & 85.7 & 90.3 & 86.9 & 81.1 \\
\hline $125-63$ & 0.5 & 0.6 & 1.0 & 0.4 & 6.5 & 0.6 & 7.2 \\
\hline$<63$ & 0.2 & 0.1 & 0.5 & 0.1 & 0.4 & 0.2 & 8.8 \\
\hline Average grain size [ m] & 206.3 & 198.3 & 217.1 & 212.7 & 186.1 & 209.7 & 174.4 \\
\hline Sorting factor & 1.257 & 1.199 & 1.337 & 1.284 & 1.253 & 1.276 & 1.550 \\
\hline
\end{tabular}


senting the terrain were classified automatically and a density of 0.21 points per $\mathrm{m}^{2}$ was received (Estonian Land Board, 2011).

Bilinear interpolation was used to create missing terrain altitudes in areas where point density was less than 2 points per $\mathrm{m}^{2}$. Resolution of the digital terrain model used in this study was $2 \times 2 \mathrm{~m}$ on the ground (Fig. 1C).

\section{GROUND-PENETRATING RADAR STUDY}

The GPR surveys were performed with a Zond 12-e system by Radar Systems Inc., using a common offset configuration with a co-polarized $300 \mathrm{MHz}$ centre frequency shielded antenna oriented perpendicular to the profile. The antennae were pulled along the forest roads at walking speed in July 2010. Three geophysical profiles with a total length of $\sim 11 \mathrm{~km}$ and perpendicular to the coastline (also normal to the ridges) were used to image the stratigraphy of the Narva-Joesuu ridges. One $\sim 2.5 \mathrm{~km}$ long profile, also sampled for optical dating, is used here as a representative example. The GPR signals were triggered at constant spacing $(10 \mathrm{~cm})$ by an odometer wheel and coordinated with the help of a portable GPS instrument (Altina GGM309; position accuracy 5-25 m) connected to the radar. The accuracy of positional data in the forested area was sometimes insufficient and therefore coordinates were corrected based on digital elevation data and depth of groundwater level on GPR sections. To amplify the reflections and reduce the noise level, stacking of four measurements was applied. The data were recorded using a $300 \mathrm{~ns}$ time window. The zero-time position (representing the first break record) was computed automatically by the radar device software.

Post-processing of the GPR data was performed with Prism2 software. A signal saturation correction (band-pass filter) was applied to the recorded data to remove low-frequency $(<100 \mathrm{MHz})$ induction effects. For better visualization of deeper reflections a time-dependent gain was used. Also, correction for topography was applied, whereas elevations were derived from airborne LIDAR data by the Estonian Land Board. Elevations were derived for every $2 \mathrm{~m}$ along the profile, which reflects general topography well, but does not contain smaller local variations that cause minor undulations of reflections in the cross-sections. Velocities were analysed by fitting hyperbolas to numerous point source reflections and diffractions. It was found that permittivity increased with depth: (1) relative dielectric permittivity within a range from 4 to 9 characterizes the topmost sands above the groundwater level, but (2) the permittivity values are much higher for water-saturated sediments, mostly between 10 and 30 . The travel time was converted to the depth scale using median relative permittivity values of 6 and 19 for the sections above and below the groundwater table, respectively.

\section{RESULTS}

\section{OSL AGES AND GEOMORPHOLOGY OF THE FOREDUNE PLAIN}

Eleven samples from the Narva-Joesuu foredune plain were OSL dated (Table 1, Figs. 1 and 3). Sample OSL12 did not provide any specific age due to very wide equivalent dose distribution and OSL5 was considered to be poorly bleached, thus giving a clearly too old age. All other samples were used together with airborne LIDAR data for interpretation of the development of the foredune plain. The OSL ages of samples OSL6 and 8-11 indicate a continuous succession of coastal foredunes and were used for calculation of foredune progradation rates and for estimation of average foredune formation times (Table 3 and Fig. 2).
Visual analysis of shaded relief images and cross-sections revealed around 100 ridges in the Narva-Joesuu foredune plain. However, some of these ridges have obviously disappeared or merged into larger landforms (Fig. 4). Together with the OSL ages the ridges can be tentatively grouped into four zones (Figs. 1 and 4). Distal zone $A$ is characterized by rather impressive multi-ridge formations with relative elevations of 2.0-4.0 $\mathrm{m}$ and a ridge interval of 60-80 m (Fig. 4). Altogether 15 ridges correspond to this zone. The highest ridges, located in the proximal part of this zone, show an age of $10.3 \pm 1.8 \mathrm{ka} \mathrm{BP}$ (sample OSL4) corresponding to the Ancylus Lake stage (Fig. 2). The morphology and OSL ages (OSL2 and OSL3) of the ridges from the distal part of this zone indicate that these ridges were re-blown during the low water level phase in the Baltic Sea around 9.0 ka BP (Fig. 2).

Ridges of zone $B$ are typically uniformly straight and parallel and have retained their natural rhythmic character (Fig. 1C). Altogether 40 ridges correspond to this zone. Most of them have strictly co-linear structure with an average ridge interval of 21-27 m. More dominant complexes with a relative height of $1.5-2.5 \mathrm{~m}$ appear at intervals of $\sim 100 \mathrm{~m}$. The foot elevations of the ridges rise from $\sim 9.5$ to $11.5 \mathrm{~m}$ a.s.l. in the NE part of the foredune plain, but remain relatively stable in the SW part (Fig. 4). From sample OSL8 onwards, the OSL ages become continuously younger, indicating the progradation of the foredune plain in conditions of falling Litorina Sea level (Figs. 1 and 2). A belt of sinusoidal dunes at the proximal end of this zone is dated to $5.4 \pm 0.9 \mathrm{ka} \mathrm{BP} \mathrm{(Fig.} \mathrm{2).}$

The ridges of zone $\mathrm{C}$ are also typically uniformly straight and parallel, but their foot elevations decrease from 11 to $5 \mathrm{~m}$ a.s.l. (Figs. 1C and 4), following the morphology of the coastal slope inherited from the till topography (Lepland et al., 1996). The OSL ages of samples OSL8-11 indicate that 39 ridges of zone C were formed between 6.0 and $3.0 \mathrm{ka} \mathrm{BP}$ (Fig. 1).

Close to the sea, a 400-600 m wide belt (zone D) consists of 19 ridges that were formed during the last $3.0 \mathrm{ka} \mathrm{BP}$. Two remarkable high ridges, in the central part of zone $D$ and at the end of the present-day backshore, strongly influenced by human activity, still persist with a relative height up to $3 \mathrm{~m}$ (Fig. 4).

The average progradation rate during the Litorina Sea regression phase between 7.1 and $3.0 \mathrm{ka} \mathrm{BP}$ was $0.31 \mathrm{~m} / \mathrm{yr}$ ( Table 3). Altogether 54 ridges formed during this period, thus it took 76 years, as an average, for a single ridge to form. During the last 3000 years the progradation rate decreased to $0.19 \mathrm{~m} / \mathrm{yr}$ together with twofold increasing foredune formation time (Table 3). An attempt was made to estimate the formation time of the last foredune at the end of the backshore from maps dating back to the 18th century. The oldest map representing dunes in the Narva-Joesuu area comes from the year 1732. Martin and Schwartz (1991) reproduced a map showing the locations of shorelines and dunes in 1765 and 1769. Unfortunately, maps of that time are geometrically unreliable, distorting different elements unequally. Nevertheless, maps dated to $1769 \mathrm{AD}$ and $1880 \mathrm{AD}$ suggest that the youngest ridge was formed between these years. This gives a time of ca. 130-240 years for the formation of the last foredune ridge, which is roughly comparable with the average calculated foredune formation time for the last 3000 years (Table 3 ). Analyses of these maps also indicate that ca. $550 \mathrm{~m}$ long spit-like coastal landform was formed in the Narva River mouth between 1769 AD and $1880 \mathrm{AD}$ (Fig. 1C).

\section{INNER STRUCTURE OF THE FOREDUNE PLAIN}

The GPR images revealed five characteristic features (from top to bottom): (1) rare landward-dipping reflections in the uppermost parts of the ridges, (2) numerous seaward-dipping reflec- 
OSL2 (peak 1)

$\mathrm{N}=3$ Mean $=580.8 \pm 48.31$

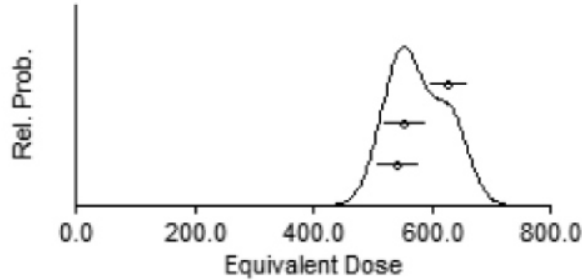

OSL4

$\mathrm{N}=10$ Mean $=660.2 \pm 62.75$

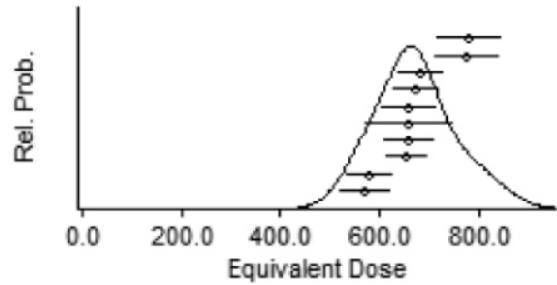

OSL6 (peak 2)

$\mathrm{N}=7$ Mean $=515.7 \pm 28.64$

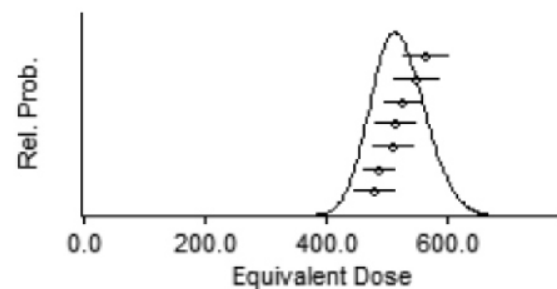

OSL9

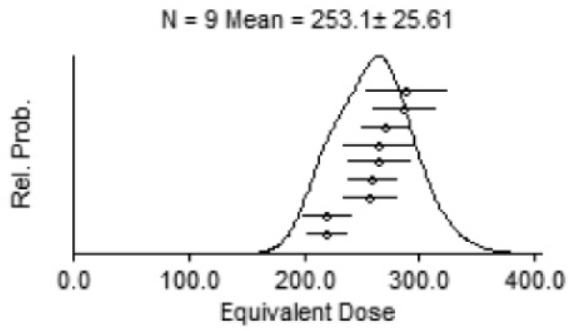

OSL12

$\mathrm{N}=14$ Mean $=62.3 \pm 25.69$

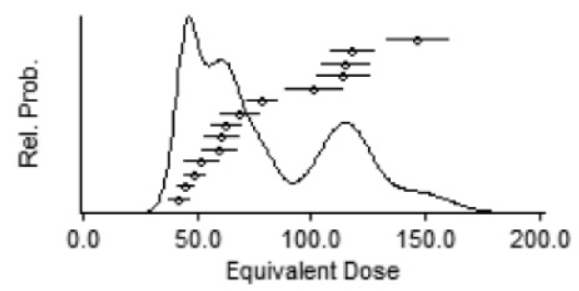

OSL2 (peak 2)

$\mathrm{N}=4$ Mean $=785.7 \pm 39.22$

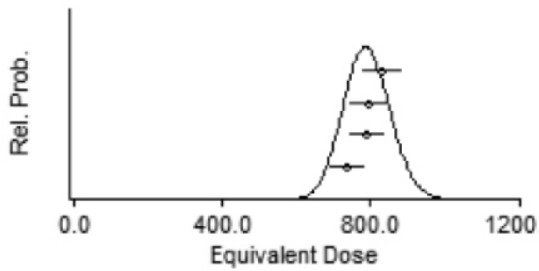

OSL5

$N=4$ Mean $=792.1 \pm 53.81$

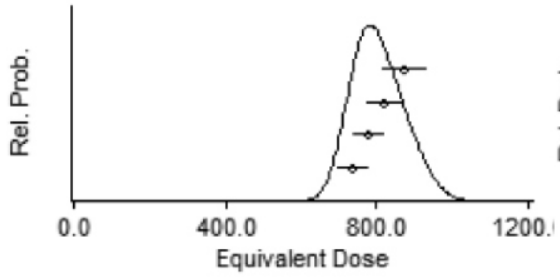

OSL7

$\mathrm{N}=9$ Mean $=291.2 \pm 27.18$

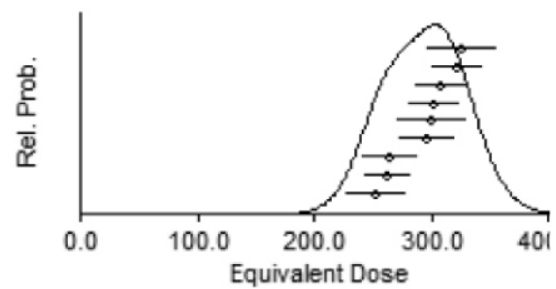

OSL10

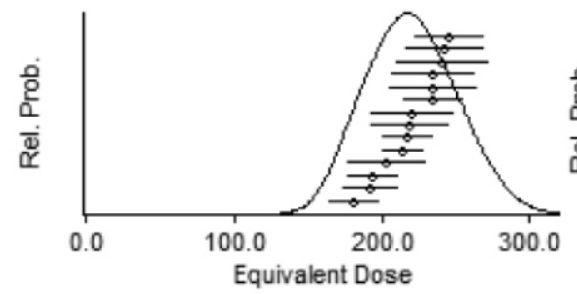

OSL3

$\mathrm{N}=8$ Mean $=481.1 \pm 40.02$

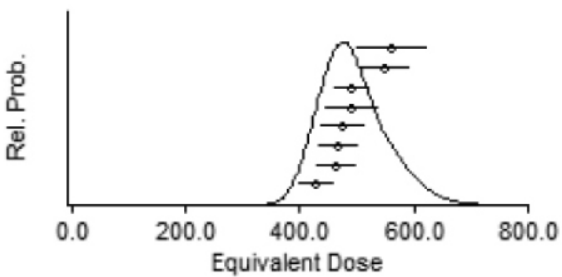

OSL6 (peak 1)

$\mathrm{N}=9$ Mean $=403.6 \pm 35.04$

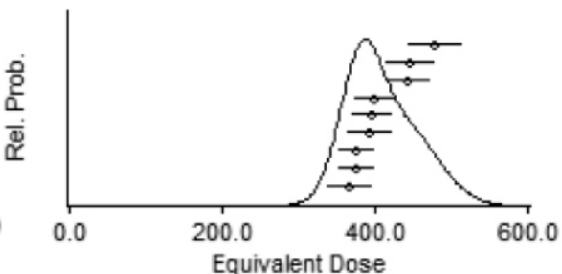

OSL8

$N=10$ Mean $=300.9 \pm 32.37$

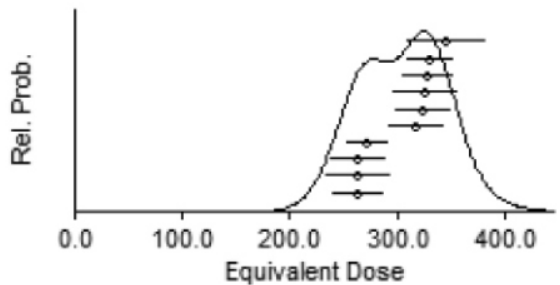

OSL11

$N=15$ Mean $=153.8 \pm 12.15$

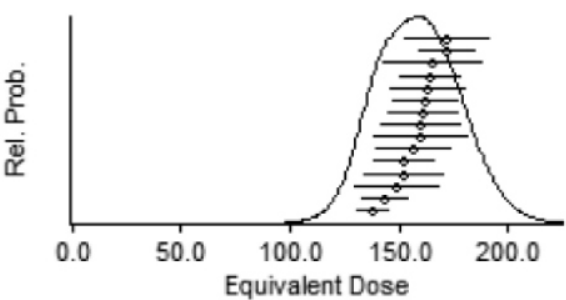

Fig. 3. Histograms of measured palaeodoses of OSL samples 
Calculated progradation rates and average foredune formation ages for Litorina Sea ridges

\begin{tabular}{|c|c|c|c|c|c|}
\hline Interval & Age $[k a$ BP] & $\begin{array}{l}\text { Distance } \\
{[\mathrm{m}]^{*}}\end{array}$ & $\begin{array}{l}\text { Progradation rate } \\
{[\mathrm{m} / \mathrm{yr}]}\end{array}$ & Number of foredune ridges & $\begin{array}{l}\text { Foredune formation rate } \\
\text { [yr/ridge] }\end{array}$ \\
\hline OSL6-8 & $7.1 \ldots 6.0$ & 1840 & 0.31 & 15 & 73 \\
\hline OSL8, 9 & $6.0 \ldots 5.2$ & 1500 & 0.30 & 9 & 89 \\
\hline OSL9, 10 & $5.2 \ldots 4.7$ & 1260 & 0.60 & 14 & 36 \\
\hline OSL10, 11 & $4.7 \ldots 3.0$ & 960 & 0.23 & 16 & 106 \\
\hline OSL11-present & $3.0 \ldots 0.0$ & 575 & 0.19 & 19 & 158 \\
\hline Average (OSL6-present) & & & 0.26 & & 97 \\
\hline
\end{tabular}

*distance is calculated from the youngest foredune foot (55 m from the present shoreline)

tions, (3) a high-amplitude subhorizontal reflection corresponding to the water table, (4) hyperbolic reflections originating from "point-sources" and (5) deep sub-horizontal parallel reflections. The radar images and interpretations are given in Figures 5 and 6 .

Rare landward-dipping (with a dip of 23 to $26^{\circ}$; calculated assuming a mean value 6 of relative dielectric permittivity) reflections (radar package A) occur on landward sides of the two highest ridges in the central part of the plain. Although landward dipping reflections are characteristic of coastal dunes (Ramos et al., 2011), these likely correspond to bounding surfaces of aeolian sands with a maximum thickness of $\sim 3 \mathrm{~m}$ (Figs. 1C, 5 and $6 \mathrm{~B}$ ). The landward-dipping reflections are either not present in other ridges or remain in a GPR shadow zone that is usually the uppermost $\sim 0.5 \mathrm{~m}$. In places the sediments in the uppermost $\sim 1 \mathrm{~m}$ have no internal reflectivity, but occasionally seaward-inclined reflectors from radar package $\mathrm{M}$ (described below) extend to the shadow zone (usually on the seaward sides of ridges).

The most voluminous radar package (M; Fig. 5) with an average thickness of $\sim 6 \mathrm{~m}$ is characterized by numerous seaward-dipping reflections (Fig. 6C). The direction of tilting (with dip up to $12^{\circ}, 7^{\circ}$ on average; calculated as based on the average relative dielectric permittivity value of 19) clearly indicates the coastal depositional environment of these sands and possibly gravels (similar studies by Neal et al., 2002; Dickson et al., 2009). The reflections that represent bounding surfaces and unconformities are generally wavy, occasionally lenticular, and usually not over $20 \mathrm{~m}$ in length. However, our test profiles parallel to ridges (along the ancient beach line) show horizontality and much longer elongation of these reflections. The signal penetration is generally good, usually $>10 \mathrm{~m}$ [except on the most landward (southeastern) side of the profiles where soil and organic sediments cover the sands], indicating low electrical conductivity (low content of clay and freshwater conditions). The groundwater table is observable as a high-amplitude continuous reflection in the central highest portion of the ridges (Fig. 5B); elsewhere it obviously remains in the shadow zone.

Package $M$ contains numerous point-source reflections which appear as diagnostic hyperbolic (convex-up) anomalies in contrast to the above-described relatively continuous features (Fig. 6A). Usually, in post-glacial conditions, such anomalies are caused by rock boulders. However, as the area is poor in boulders and no such features occur within the underlying package L, narrow lenses of gravel as observed by Lepland et al. (1996) in a quarry wall at the Sininomme beach ridge system (Fig. 1C) or, alternatively, tree stumps (case studies of buried organic material by, e.g., Kearney, 1996; Barton and Montagu, 2004; Buynevich et al., 2010), may cause the hyperbolic anomalies. However, there is no geological evidence of Holocene tree stumps in the coastal deposits of Estonia. We note that the concentration of the point-source reflections is significantly higher within the seaward side of the beach ridge, and especially high in the lowermost part, close to the lower boundary of package $\mathrm{M}$.

The pattern of the lowermost radar package $(L)$ is distinctly different from those of the higher packages. It is characterized by closely spaced parallel and almost horizontal reflections indicative of calm deep-water sedimentation conditions. The boundary between packages $M$ and $L$ is erosional, as witnessed by incisions of the overlying marine sands and gravels into package $\mathrm{L}$. The level of erosion is slightly deeper in the central part of the Narva-Joesuu foredune plain where package $L$ also is at higher elevations. Incisions, gravel lenses, and/or tree stumps are responsible for the hyperbolic features on the GPR sections at or near the $\mathrm{M}-\mathrm{L}$ boundary. The surface remains hidden on the landward (southeastern) side of the illustrative profile (Fig. 6). However, it is identified by applying the GPR at other sites (Kudruküla, Sininomme), near Narva-Joesuu lying at 0-3 m a.s.I (Fig. 1). The reflection pattern of radar package $L$ suggests its formation during the Baltic lce Lake before 11.7 cal. ka BP when the altitude of water level in the study area was at least $35 \mathrm{~m}$ (Rosentau et al., 2009). Erosion of package $L$ has probably taken place during the regression of the Yoldia Sea (Fig. 2).

\section{DISCUSSION}

Our OSL ages and geomorphological analyses support the idea of the formation of the distal part (zone A in Fig. 1C) of the Narva-Joesuu foredune plain before the Litorina transgression, most probably during the regressive phase of the Ancylus Lake/Early Litorina Sea, as suggested by Lepland et al. (1996). According to the Narva-Luga shore displacement curves (Fig. 2), the Ancylus Lake/Early Litorina Sea regression took place between 10.2 and 8.5 cal. ka BP, which corresponds approximately to the ages of samples OSL2-4. During the regression the water level reached its lowest elevation at $\sim 2 \mathrm{~m}$ a.s.l. and subaerial conditions existed in the distal part of the Narva-Joesuu ridge complex. The younger ages of samples OSL2 and 3 compared to OSL4 indicate that the upper (at least $1.5 \mathrm{~m}$ ) and more distal part of this ridge complex was re-blown during the low water level episode before the Litorina transgression. Farther to the south-east, in the Leekovosoo Basin, gyttja-peat formed at that time with a high degree of scatter in magnetic concentrations (Fig. 7), indicating the input of wind-blown material from the Narva-Joesuu beach ridge system (Lepland et al., 1996).

During the relatively rapid Litorina Sea transgression the water level rose $8 \mathrm{~m}$ in the Narva-Joesuu area between 8.5 and $7.3 \mathrm{cal}$. ka BP (Figs. 1B and 2). At that time the seaward part of 
PROFILE 1

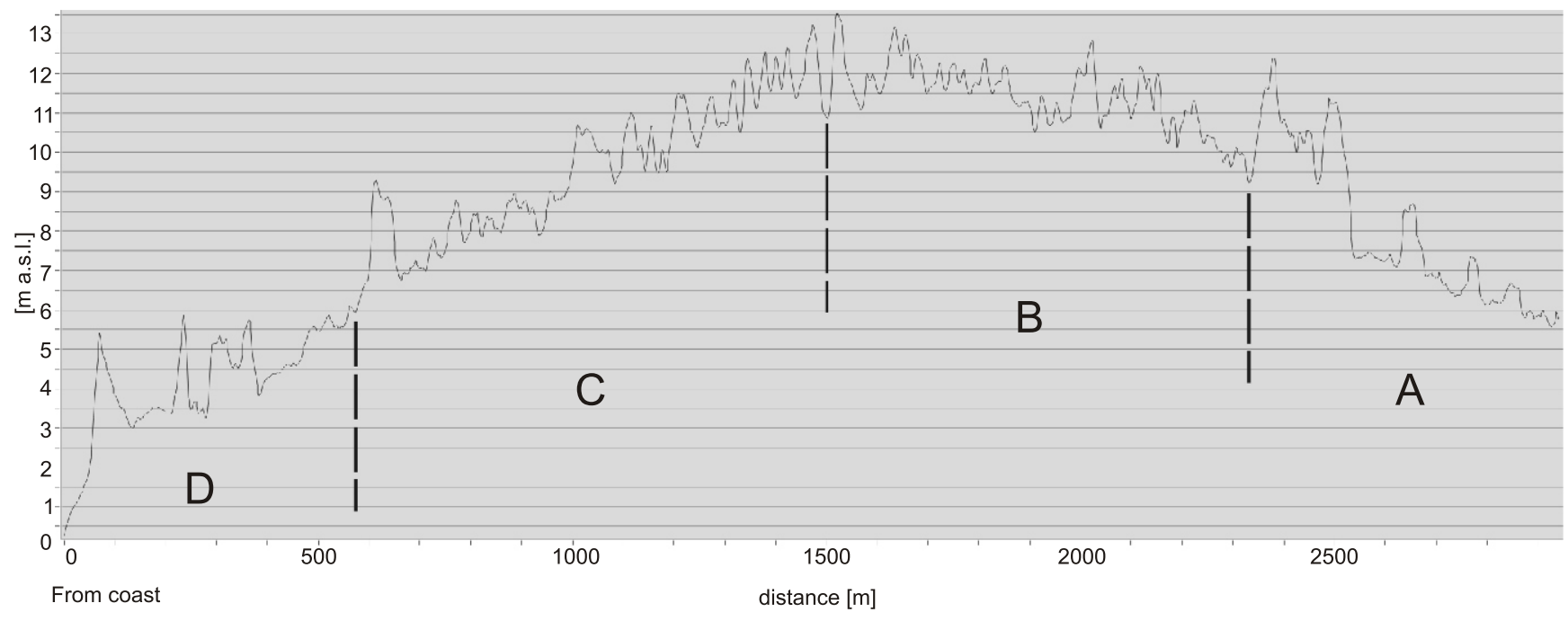

PROFILE 2

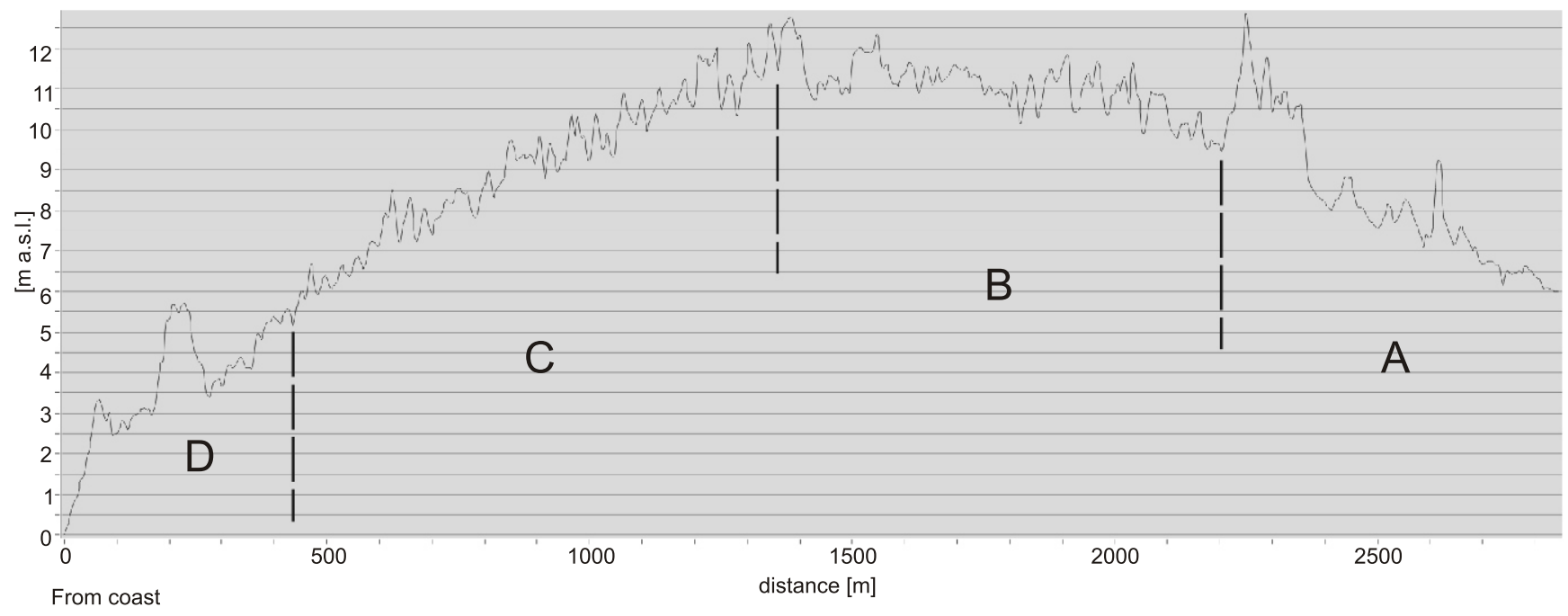

PROFILE 3

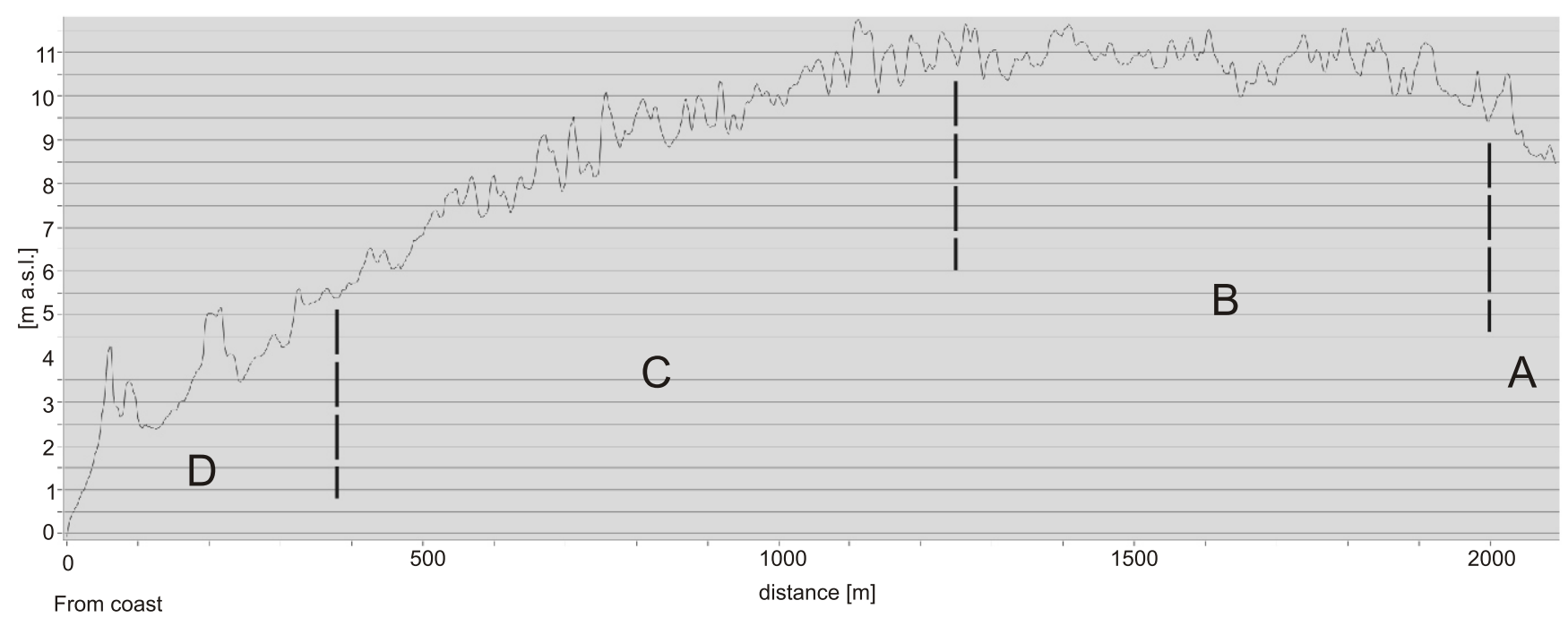

Fig. 4. Geomorphological profiles across the Narva-Joesuu foredune plain with indication of identified geomorphic zones Location of profiles is shown in Figure 1C; A-D - foredune zones 

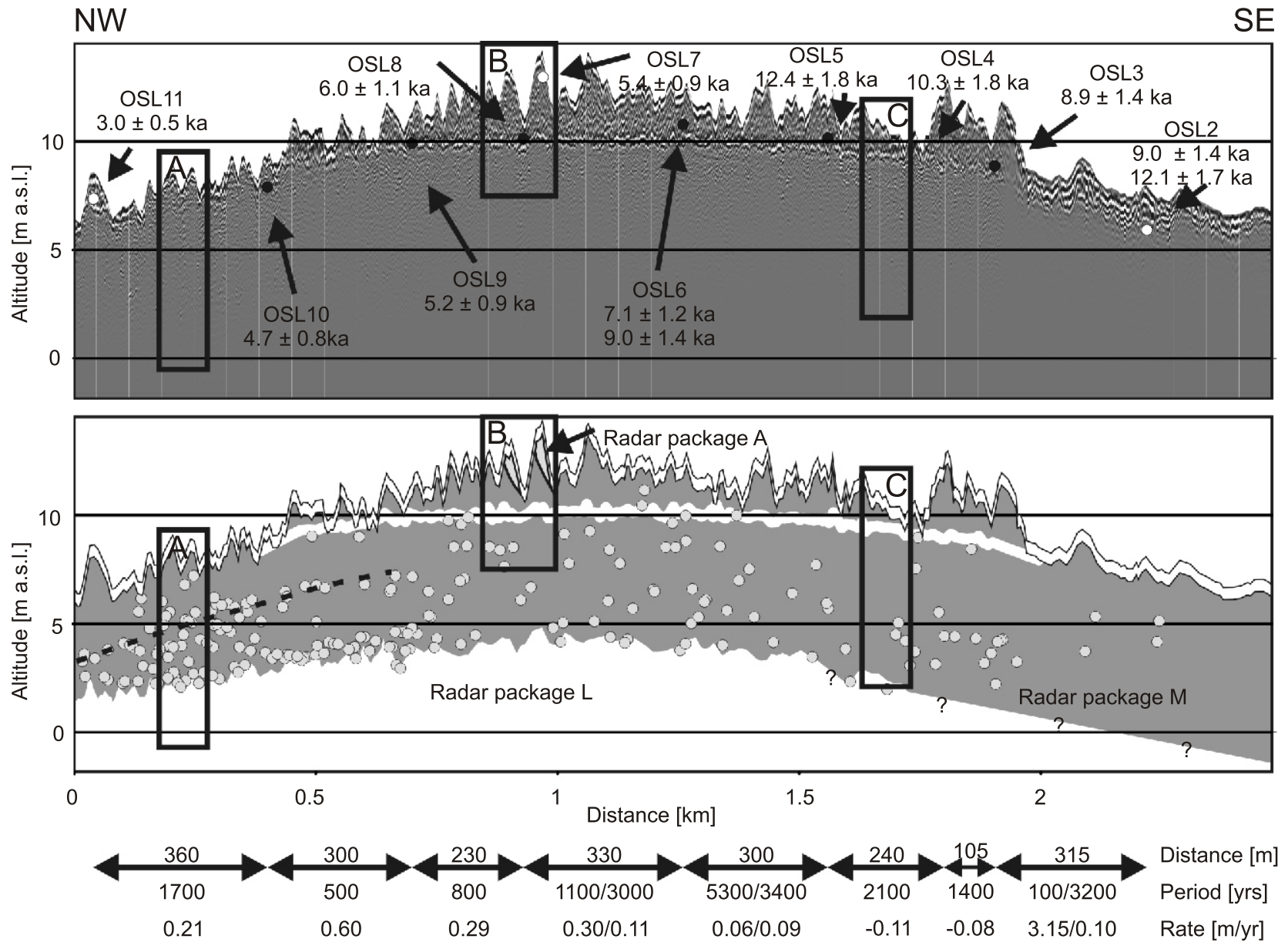

Fig. 5. The upper figure represents an illustrative ground-penetrating radar image along the profile 1 (Fig. 1C) showing sampling sites (black and white dots indicate samplings at and off the profile, respectively) for OSL dating; the lower figure shows an interpreted section where radar packages $A, M$, and $L$ are given

The uppermost white stripe (lower figure) indicates the radar shadow zone, the white line is water table, white dots show locations of major hyperbolic reflections; rectangles $(A-C)$ correspond to detailed views in Figure 6; the vertical scale is exaggerated 45 times

the coastal landform system which formed during the regression of the Ancylus Lake/Early Litorina Sea was most probably reworked. Our OSL ages and geomorphological analyses indicate that the Litorina Sea shoreline was transgressed to the south-east from sampling site OSL6 (Fig. 1C), and was located somewhere in between sampling sites OSL6 and 4. In the Leekovosoo Basin, the Litorina Sea transgression is reflected by the deposition of lagoonal detritus gyttja indicating that the active wave regime did not enter the basin (Lepland et al., 1996). However, the high degree of scatter in magnetic concentrations in lagoonal deposits still shows input of wind-blown material from the Narva-Joesuu area (Fig. 7).

Interestingly, radar package $\mathrm{M}$ does not contain a clear erosional surface that could be associated with the Litorina Sea transgression. Both sands of initial ridges of Ancylus Lake age and later Litorina Sea ridges formed in similar coastal hydrodynamic conditions and are composed of well-sorted fine sands with similar grain size distribution (Table 2). Quite probably Ancylus Lake beach deposits are preserved below Litorina Sea deposits in the lower portion of radar package $M$, as the potential for preservation of older sediments is usually much higher during a rapid transgression than during a slowly rising sea level (Cooper, 2007). During the Litorina Sea transgression the uppermost part (at least $1 \mathrm{~m}$ ) of older sandy deposits must have been reworked as bars and has indistinguishably merged with younger deposits. Despite the uniform reflector pattern of coastal sands and lack of a clear surface within it, the erosional period and water level lowstand before the Litorina transgression could be associated with numerous hyperbolic features in radar package $\mathrm{M}$ that tend to align 2-3 $\mathrm{m}$ above the base of the package in the NW part of the profile studied. In the seaward part of the beach ridge system the hyperbolas originate from objects within the 1-1.5 m depth range. Such a depth range could mark the reworking depth of older sediments, while these reflective objects are gravel lenses or tree stumps that were buried in transgressive conditions. In the central and landward parts of the ridge system the alignment of hyperbolic features is not clear and could indicate a lesser hydrodynamic regime on a flatter coast.

A succession of at least 73 ridges was formed in the proximal part of the foredune plain in conditions of falling relative sea level during the Litorina regression at an average progradation rate of $0.26 \mathrm{~m} / \mathrm{yr}$ (Table 3). There is no evidence of the formation of the transgressive Litorina Sea shoreline in the highest central part of the ridge system as suggested by Lepland et al. (1996). Our OSL ages indicate that the ridges in the central part of the plain were formed already in the conditions of the falling Litorina Sea level around 6.0 ka BP (Fig. 2).

Generally systematic progradation of the foredune plain with the formation of relatively straight and parallel ridges was 

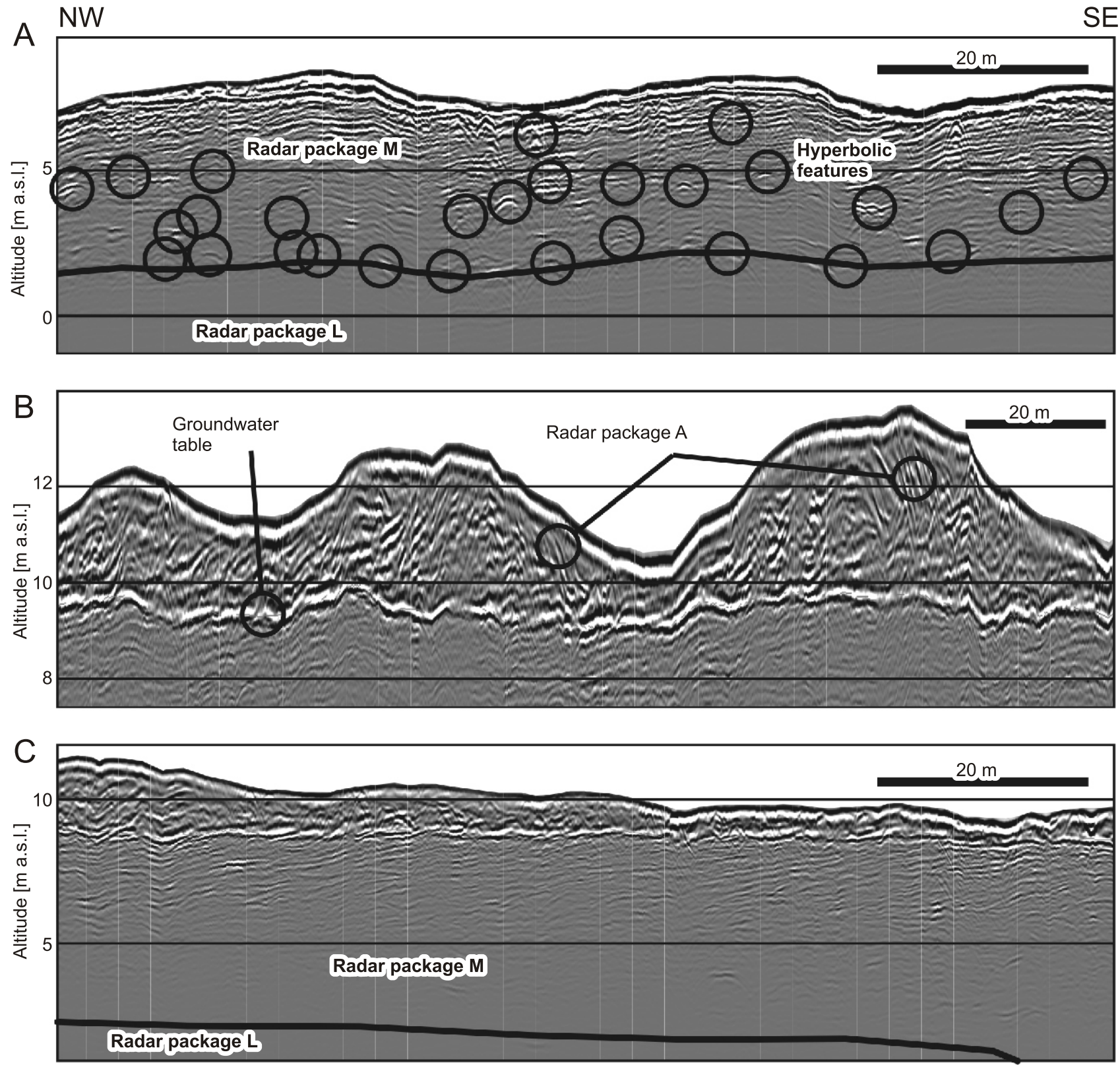

Fig. 6. Detailed radar images along the profile 1 (Fig. 1C)

A - radar packages $\mathrm{M}$ and $\mathrm{L}$, and hyperbolic reflections within package $\mathrm{M} ; \mathbf{B}$ - two positions where landward-dipping reflections of likely aeolian origin (radar package A) were detected; the high-amplitude reflection is due to groundwater table; $\mathbf{C}$ - typical seaward-dipping pattern of reflections within radar package $\mathrm{M}$; the vertical scales are exaggerated $3.3(\mathrm{~A}), 7.0$ (B) and 3.4 (C) times

disrupted by an episode of foredune instability in the central part of the plain around $5.4 \pm 0.9 \mathrm{ka} \mathrm{BP}$. The inner structure and morphology of this ridge complex together with OSL ages indicate that initial foredune ridges have been subject to re-blowing, forming blowouts and sinusoidal dunes, whereas the active shoreline was nearby, probably no farther than about $200 \mathrm{~m}$ (Fig. 1C). This foredune instability and re-blowing episode could be correlated with a short-term but clear increase in magnetic concentrations in Leekovosoo lagoonal gyttja deposits. According to the age-depth model this increase is dated to $\sim 5.5$ cal. ka BP (Fig. 7), and may be related to colder and probably more stormier conditions at that time. Pollen-based annual mean temperature reconstructions from northern Europe indicate colder annual temperatures of around 5.3 cal. ka BP (Seppä et al., 2009). Sommer et al. (2009) showed that the regional extirpation of the European pond turtle, a temperate species intolerant of cold summers, happened in Fennoscandia at about 5.5 cal. ka BP, probably due to a cold spell. Evidence for a large regional cooling at 5.8-5.1 cal. ka BP has been reported from the North Atlantic and central Europe (Oppo et al., 2003; Magny and Haas, 2004; Moros et al., 2004; Vollweiler et al., 2006), and from the strong signal in the Greenland glaciochemical proxies (Mayewski et al., 1997).

Foredune ridges that formed during the last $3.0 \mathrm{ka}$ BP show high relative elevations in the central part of zone $\mathrm{D}$ and at the end of the present-day backshore (Fig. 4). The formation of higher ridges together with a decreased progradation rate and increased time for the formation of a single ridge (Table 3) may be related to decelerated land uplift combined with LIA-type climatic events and human impact. Reimann et al. (2011) described three LIA-type foredune mobilization and instability periods in the southern Baltic related to major climate shifts towards cooler and stormier conditions at $2.9 \mathrm{cal}$ ka BP, $600 \mathrm{AD}$ and $1600 \mathrm{AD}$ during the last 3000 years. In the Leekovosoo Basin 


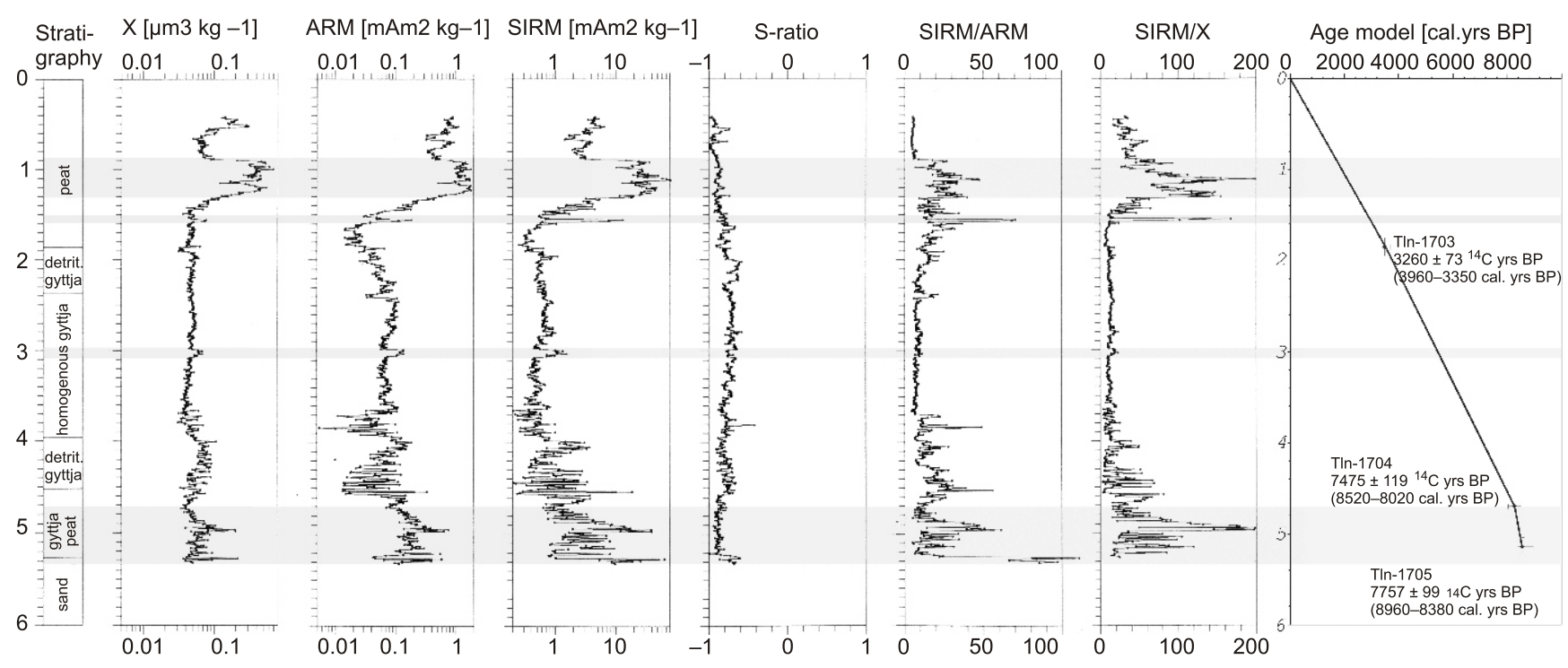

Fig. 7. Lithological composition, magnetic parameters and radiocarbon dates of the Hoovi sequence from the Leekovasoo mire according to Lepland et al. (1996) together with the age-depth model and indication of zones related to higher input of fine-grained wind-blown material

All radiocarbon dates in the age-depth model were calibrated using IntCal09 calibration curve (Reimer et al., 2009) and presented with $1 \sigma$ confidence level; location of the Hoovi sequence is shown in Figure $1 \mathrm{C}$

peat deposits formed at about 3.0-1.6 cal ka BP are characterized by a high degree of scatter in magnetic concentrations, indicating two episodes of higher input of wind-blown material (Fig. 7). Unfortunately, we failed to date the high ridge in the central part of zone $\mathrm{D}$ due to very wide equivalent dose distribution and therefore cannot relate the results to any climatic events. The development of the youngest foredune ridge is strongly influenced by increased human impact, including coastal protection in the Narva River mouth since the second half of the 18th century (Martin and Schwartz, 1991) and development of the Narva-Joesuu resort.

Although OSL ages were found to be useful for clarifying the progradation history of the foredune plain, their use for estimations of past sea level is rather difficult. Comparison of OSL dating series with radiocarbon dated relative sea level curves indicates that large standard deviations complicate the use of OSL ages in high-resolution shore displacement studies. Moreover, the difference between OSL-dated backshore upper limits and mean relative sea levels in the shore displacement curve is not constant but increases with time (Fig. 2). Linden et al. (2006) noted a similar trend when comparing the radiocarbon-dated Litorina Sea level curve with OSL ages in Norrbotten, Sweden.

\section{CONCLUSIONS}

The Narva-Joesuu foredune plain consists of $\sim 100$ parallel coastal foredune ridges built of well-sorted fine sand and underlain by gently $\left(\sim 7^{\circ}\right)$ seaward-dipping sandy beach deposits. The distal part of the plain consisting of at least 15 ridges formed during the regression phase of the Ancylus Lake/Early Litorina
Sea, constituting a barrier for the Leekovosoo lagoon behind it. Most of the ridges, with an average progradation rate of $0.26 \mathrm{~m} / \mathrm{yr}$, formed in conditions of falling relative sea level during the Litorina regression and were separated from the older foredune succession by a hiatus related to the Litorina transgression at 8.5-7.3 cal. ka BP. In the highest central part of the plain the foredune growth was interrupted by foredune instability and a re-blowing episode dated to $5.4 \pm 0.9 \mathrm{ka} \mathrm{BP}$, which may correlate with more pronounced regional cooling at 5.8-5.1 cal. ka BP in the North Atlantic and central Europe. During the last 3000 years, the foredune progradation rate decreased to $0.19 \mathrm{~m} / \mathrm{yr}$ probably due to the decelerating land uplift and increased human impact.

The OSL dating of the foredune plain is useful for reconstructing the Holocene progradation history of the Narva-Joesuu foredune plain, but large standard deviations complicate its application to high-resolution relative sea level reconstructions. Future studies on more detailed chronology and the inner architecture of the foredune plain could contribute to better understanding of the long-term coastal processes and Holocene development of the area.

Acknowledgements. The authors express their thanks to M. Mustasaar for assistance in the field, $T$. Rahe for help in the field and grain-size analyses, and A. Noor and J. Zalasiewicz for revising the language. We thank $L$. Saarse, A. Bitinas and an anonymus reviewer for their helpful reviews of this paper. The research was financed by Estonian Science Foundation grants 7294 and 7860 and Estonian target funding projects SF0180048s08 and SF0180069s08 and SF0180049s09. 


\section{REFERENCES}

Aitken M.J. (1985) Thermoluminescence dating. Studies on Archaeological Science. Academic Press Inc. Ltd., London.

Andrén T., Björck S., Andren E., Conley L.Z., Anjar J. (2011) The development of the Baltic Sea Basin during the Last $130 \mathrm{ka}$. In: The Baltic Sea Basin (eds. J. Harff, S. Björck and P. Hoth): 75-97. Central and Eastern European Development Studies. Springer-Verlag, Berlin.

Ankjærgaard C., Murray A. (2007) Total beta and gamma dose rates in trapped charge dating based on beta counting. Radiation Measurements, 42: 352-359.

Barton C.V.M., Montagu K.D. (2004) Detection of tree roots and determination of root diameters by ground-penetrating radar under optimal conditions. Tree Physiology, 24: 1323-1331.

Bird E.C.F. (1984) Coasts: an introduction to coastal geomorphology. Oxford.

Bøtter-Jensen, L., Duller G.A.T. (1992) A new system for measuring OSL from quartz samples. Nuclear Tracks and Radiation Measurements, 20: 549-553.

Bøtter-Jensen L., Mejdahl V., Murray A.S. (1999) New light on OSL. Quaternary Geochronology, 18: 303-309.

Buynevich I.V., Souza Filho P.W.M., Asp N.E. (2010) Dune advance into a coastal forest, equatorial Brazil: a subsurface perspective. Aeolian Research, 2: 27-32.

Cooper J.A.G. (2007) High energy coasts sedimentary indicators. In: Encyclopedia of Quaternary Science (ed. S.A. Elias): 2983-2993. Elsevier, London.

Dickson M.E., Bristow C.S., Hicks D.M., Jol H., Stapleton J., Todd D. (2009) Beach volume on an eroding sand-gravel coast determined using ground penetrating radar. Journal of Coastal Research, 255: 1149-1159.

Ekman M. (1996) A consistent map of the postglacial uplift of Fennoscandia. Terra Nova, 8: 158-165.

Estonian Land Board (2011) Elevation data. Estonian Land Board, Tallinn. http://geoportaal.maaamet.ee/est/Andmed-ja-kaardid/ Topograafilised-andmed/Korgusandmed-p114.htm (review in English: http://geoportaal.maaamet.ee/eng/Maps-and-Data/Topographic-data/Elevation-data-p308.html) (07.10.2012).

Galbraith R.F. (1990) The radial plot: graphical assessment of spread in ages. Nuclear Tracks and Radiation Measurements, 17: 207-214.

Hesp P. (2002) Foredunes and blowouts: initiation, geomorphology and dynamics. Geomorphology, 48: 245-268.

Kearney M.S. (1996) Sea-level change during the last thousand years in Chesapeake Bay. Journal of Coastal Research, 12 977-983.

Lepland A., Hang T., Kihno K., Sakson M., Sandgren P., Lepland A. (1996) Holocene sea-level changes and environmental history in the Narva area, North-eastern Estonia. In: Coastal Estonia: Recent Advances in Environmental and Cultural History (ed. T. Hackens): 314-358. Rixensart PACT, Belgium.

Linden M., Möller P., Björck S., Sandgren P. (2006) Holocene shore displacement and deglaciation chronology in Norrbotten, Sweden. Boreas, 35: 1-22.

Magny M., Haas J.N. (2004) A major widespread climatic change around $5300 \mathrm{cal}$. yr BP at the time of the Alpine Iceman. Journal of Quaternary Science, 19: 423-430.

Martin E., Schwartz M. (1991) Geomorphic evolution of the Narva-Luuga Coast, U.S.S.R. Shore and Beach, 59 (2): 28-32.

Mayewski P.A., Meeker L.D., Twickler M.S., Whitlow S., Yang Q., Lyons W.B., Prentice M. (1997) Major features and forcing of high-latitude northern hemisphere atmospheric circulation us- ing a 110,000-year long glaciochemical series. Journal of Geophysical Research - Oceans, 102: 26345-26366.

Moros M., Emeis K., Risebrobakken B., Snowball I., Kuijpers A., McManus J., Jansen E. (2004) Sea surface temperatures and ice rafting in the Holocene North Atlantic: climate influences on Northern Europe and Greenland. Quaternary Science Reviews, 23: 2113-2126.

Murray A., Wintle A. (2000) Luminescence dating of quartz using an improved single-aliquot regenerative-dose protocol. Radiation Measurements, 32: 57-73.

Neal A., Pontee N.I., Pye K., Richards J. (2002) Internal structure of mixed-sand-and-gravel beach deposits revealed using ground-penetrating radar. Sedimentology, 49: 789-804.

Oppo D.W., McManus J.F., Cullen J.L. (2003) Deepwater variability in the Holocene epoch. Nature, 422: 277-278.

Ramos R., Freitas M.C., Bristow C.S., Andrade C., Hermozilha H., Grangeia C., Senos Matias M. (2011) Sedimentary architecture of the Santo André transverse dunes (Portugal) interpreted from ground-penetrating radar. Journal of Coastal Research, Special Issue, 57: 303-307.

Reimann T., Tsukamoto S., Harff J., Osadczuk K., Frechen M. (2011) Reconstruction of Holocene coastal foredune progradation using luminescence dating - an example from the Świna barrier (southern Baltic Sea, NW Poland). Geomorphology, 132: 1-16.

Reimer P.J., Baillie M.G.L., Bard E., Bayliss A., Beck J.W., Blackwell P.G., Bronk Ramsey C., Buck C.E., Burr G.S., Edwards R.L., Friedrich M., Grootes P.M., Guilderson T.P., Hajdas I., Heaton T.J., Hogg A.G., Hughen K.A., Kaiser K.F., Kromer B., McCormac F.G., Manning S.W., Reimer R.W., Richards D.A., Southon J.R., Talamo S., Turney C.S.M., van der Plicht J., Weyhenmeyer C.E. (2009) IntCal09 and Marine09 radiocarbon age calibration curves, $0-50,000$ years cal BP. Radiocarbon, 51 (4): 1111-1150.

Rosentau A., Vassiljev J., Hang T., Saarse L., Kalm V. (2009) Development of the Baltic Ice Lake in eastern Baltic. Quaternary International, 206: 16-23.

Rosentau A., Muru M., Kriiska A., Subetto D.A., Vassiljev J., Hang T., Gerassimov D., Nordqvist K., Ludikova A., L ugas L., Raig H., Kihno K., Aunap R., Letyka N. (2013) Stone Age settlement and Holocene shore displacement in the Narva-Luga Klint Bay area, eastern Gulf of Finland. Boreas: DOI: 10.1111/bor.12004

Saarse L., Vassiljev J., Miidel A. (2003) Simulation of the Baltic Sea shorelines in Estonia and neighbouring areas. Journal of Coastal Research, 19 (2): 261-268.

Sandgren P., Subetto D.A., Berglund B.E., Davydova N.N., Savelieva L.A. (2004) Mid-Holocene Littorina Sea transgressions based on stratigraphic studies in coastal lakes of NW Russia. GFF, 126: 363-380.

Seppä H., Bjune A.E., Telford R.J., Birks H.J.B., Veski S. (2009) Last nine-thousand years of temperature variability in Northern Europe. Climate of the Past, 5: 523-535.

Sommer R.S., Lindqvist C., Persson A., Bringsøe H., Rhodin A.G., Schneeweiss N., Sirok P., Bachmann L., Fritz U. (2009) Unexpected early extinction of the European pond turtle (Emys orbicularis) in Sweden and climatic impacts on its Holocene range. Molecular Ecology, 18: 1252-1262.

Vollweiler N., Scholz D., Mühlinghaus C., Mangini A., Spötl C. (2006) A precisely dated climate record for the last $9 \mathrm{kyr}$ from three high alpine stalagmites, Spannagel Cave, Austria. Geophysical Research Letters, 33: L20703, doi:10.1029/2006GL027662 